\title{
What biological evolution teaches about sustainable engineering innovation
}

Jurgen Poesche, Oleg Shipin, Yang Liu, Donald Huisingh and Ilkka Kauranen

The self-archived postprint version of this journal article is available at Linköping University Institutional Repository (DiVA):

http://urn.kb.se/resolve?urn=urn:nbn:se:liu:diva-161116

N.B.: When citing this work, cite the original publication.

Poesche, J., Shipin, O., Liu, Y., Huisingh, D., Kauranen, I., (2019), What biological evolution teaches about sustainable engineering innovation, Journal of Cleaner Production, 240, UNSP 118267.

https://doi.org/10.1016/j.jclepro.2019.118267

Original publication available at:

https://doi.org/10.1016/j.jclepro.2019.118267

Copyright: Elsevier

http://www.elsevier.com/

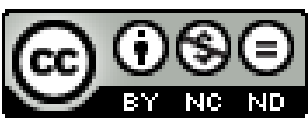




\section{Journal Pre-proof}

What biological evolution teaches about sustainable engineering innovation

Jurgen Poesche, Oleg Shipin, Yang Liu, Donald Huisingh, Ilkka Kauranen

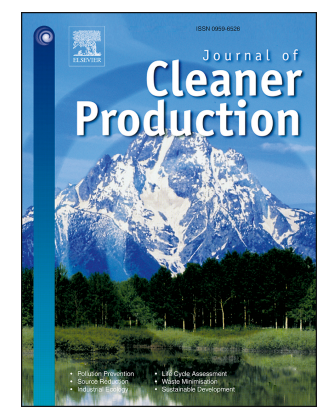

PII:

S0959-6526(19)33137-3

DOI: $\quad$ https://doi.org/10.1016/j.jclepro.2019.118267

Reference: JCLP 118267

To appear in: Journal of Cleaner Production

Received Date: 24 November 2018

Revised Date: 9 July 2019

Accepted Date: 2 September 2019

Please cite this article as: Poesche J, Shipin O, Liu Y, Huisingh D, Kauranen I, What biological evolution teaches about sustainable engineering innovation, Journal of Cleaner Production (2019), doi: https:// doi.org/10.1016/j.jclepro.2019.118267.

This is a PDF file of an article that has undergone enhancements after acceptance, such as the addition of a cover page and metadata, and formatting for readability, but it is not yet the definitive version of record. This version will undergo additional copyediting, typesetting and review before it is published in its final form, but we are providing this version to give early visibility of the article. Please note that, during the production process, errors may be discovered which could affect the content, and all legal disclaimers that apply to the journal pertain.

() 2019 Published by Elsevier Ltd. 


\title{
What biological evolution teaches about sustainable engineering innovation
}

\author{
Jurgen Poesche ${ }^{a}$, Oleg Shipin ${ }^{b}$, Yang Liu ${ }^{c, d, *}$, Donald Huisingh ${ }^{e}$, Ilkka Kauranen ${ }^{a, *}$ \\ ${ }^{a}$ Department of Industrial Engineering and Management, Aalto University, 02150 Espoo, Finland \\ ${ }^{b}$ Environmental Engineering and Management programme, Asian Institute of Technology, \\ Pathumthani 12120, Thailand \\ ${ }^{c}$ Department of Management and Engineering, Linköping University, SE-581 83 Linköping, Sweden \\ ${ }^{d}$ Department of Production, University of Vaasa, 65200 Vaasa, Finland \\ ${ }^{\mathrm{e}}$ Institute for a Secure and Sustainable Environment, University of Tennessee, Knoxville, TN, USA
}

Corresponding Authors: yang.liu@liu.se (Y. Liu), ilkka.kauranen@gmail.com (I. Kauranen)

\begin{abstract}
The objective of this paper is to provide a better understanding of the dynamics of engineering innovation by building a novel, extensive metaphor between engineering innovation and biological evolution. In a metaphor, a phrase literally denoting one kind of idea is used in place of another in order to suggest an analogy between them. In this metaphor, the insights gleaned from biological evolution were applied to engineering innovation. Biological evolution and engineering innovation are similar in that both exhibit creative destruction as evidenced by Darwin and Schumpeter. In the research analyses, special attention is given to the current multipolar world, with the poles consisting of societies based on different cultural traditions and to the emerging renaissance of decentralized production and its current iteration, Co-Engaging Production. The metaphor used in this paper challenges and even contradicts conventionally explicit and embedded beliefs in six ways. First, the dominance of Occidental science and engineering cannot be expected to last indefinitely. Second, the current dominance of Occidental science and engineering can have detrimental effects on engineering innovation. Third, free trade leads to inefficiency. Fourth, successful engineering innovation requires societal legitimacy and environmental conformity. Fifth, human cognition forms the basis of multipolar types of science and engineering. Sixth, past and current dominance reduces absorptive capacity in the Occidental.
\end{abstract}

\section{Keywords}

Biological evolution; Cognition; Engineering innovation; Legitimacy; Metaphor; Sustainability

\section{Introduction}

Applying the theories of biological evolution to engineering innovation opens the door to establishing a solid scientific foundation for studying sustainable engineering innovation. Sustainability is an inseparable part of biological evolution and, thus, sustainability in engineering innovation can better be understood by understanding biological evolution. Dynamism is a central way in how biological sustainability is reached. In order to better understand the dynamism within engineering innovation, it can be viewed by comparing it with the dynamic aspects of sustainable development in biology. In this context, it is also necessary to consider the role of diversity in biological evolution and to apply it to engineering innovation. In biology, diversity allows for ecosystems to change in response to 
external environmental changes (Wells, 2013). Each individual needs to function successfully in its own environment over its entire lifespan (Walsh, 2003). In agriculture, monocultures are biologically and economically inefficient (Igbozurike, 1978; Power and Follett, 1987). The diversity associated with polycultures is not solely a survival mechanism, but also a way to be more efficient and sustainable for the present and long-term future.

Biological evolution is a dynamic process resulting in failures and successes in the environment; and engineering innovation is a dynamic process that brings about new products and processes that either fail or succeed in society. These similarities provide valuable context for comparing biological evolution and engineering innovation, with each other.

This paper focuses on (natural) science and engineering. The direct impact of the humanities on multi-polarity is thus, excluded. However, indirect impact of the humanities via cognition and legitimation is addressed. Occidental engineering is based on Occidental cognition and culture, spreading from there into non-Occidental societies.

The objective of this research study is to provide a better understanding of the dynamics of engineering innovation by building a novel, extensive metaphor between engineering innovation and biological evolution. In this metaphor, the insights gleaned from biological evolution are applied to engineering innovation in a multipolar world, with the poles consisting of societies based on different cultural traditions.

\section{Methodology}

This research study is conceptual. It provides a better understanding of the dynamics of engineering innovation. The insights gained by this study are unique, some even contradicting conventional perceptions. Such novel, in-depth understanding provided by this study was possible by the choice of research methodology. As a research methodology, the authors drew from one branch of science - namely biology, particularly biological evolution - to create new knowledge in another branch of science - namely business, particularly engineering innovation. This choice of methodology offered the opportunity to apply principles developed in the natural sciences to the social science-related aspects of engineering innovation.

The type of research methodology used in this study is called a metaphor. A metaphor is defined to be a figure of speech in which a phrase or a word literally denoting one kind of object or idea is used in place of another in order to suggest a likeness or analogy between them (Merriam-Wester Dictionary, 2018). Correspondingly, this study is founded on a metaphor derived from biological evolution and applied to engineering innovation.

Mann and Warr (2017, p. 549) have described the research methodology based on using metaphors as a two-stage approach with the first stage comparable to a pin board on which data are assembled, and in the second stage the data are rearranged into montages allowing for interpretation from several vantage points. The resulting rearrangements are subjective as any rearrangement is dependent on the researcher's previous knowledge and personal views. Wall $(2009$, p. 38) has explained that "a metaphor finds similarity in apparently dissimilar things or situations, and combines these different elements into a single functioning image, which retains both originals while transmuting them." Wall $(2009$, p. 33) has further clarified that in science metaphors "explain, test or visualize one (novel) reality in terms of another (less novel) one". 
In this current research study, engineering innovation represents the (novel) reality that is explained, tested and visualized, and ecological evolution represents the other (less novel) reality. The comparison of these two realities constitutes the metaphor.

An essential prerequisite for building a metaphor is to identify a suitable reality that is conducive for the explanatory comparisons done by means of the metaphor. For the sake of this research, an indepth investigation of the prehistorical evolution of species was conducted. Studying the evolutionary effects of the formation of the Isthmus of Panama between North America and South America served the needs of this research. For millions of years before the isthmus was formed, there had not been any connection between the populations of mammals in South America and Australia, on the one hand, and North America, Eurasia, and Africa on the other hand. After the isthmus connected these two landmasses, migration of species between the two previously separated landmasses was possible. This event is called the Great American Biotic Interchange, which occurred 2.7 million years ago.

Biological evolution and engineering innovation, which are part of the metaphor built in this paper are similar in that both exhibit creative destruction as evidenced by Darwin (2013) and Schumpeter (1963). The dynamics found in biological evolution can, therefore, be used to better understand the dynamics seen in engineering innovation by analyzing a metaphor of these two. Using biological evolution as a metaphor for engineering innovation allows for gaining new insights into the creative destruction associated with engineering innovation. The comparison of the roles played by genotypic and phenotypic diversity in biological evolution, and the cultural and epistemic diversity in engineering innovation are of particular interest in this paper.

In research, metaphors play a particularly important role in theory building (Baedke and Schöttler, 2017). Metaphors are propitious in making hypotheses imaginable (Hampe, 2018). Metaphors can serve cognitive and heuristic aims in philosophy of science (Rentetzi, 2005). In some instances, a heuristic solution derived from using a metaphor is reached unconsciously (Fischer, 2014).

The use of metaphors is a versatile and fertile methodology. Metaphors may have argumentative, ideological, rhetorical or polemical functions in intellectual reasoning (Schlanger, 1995). A methodological strength of using a metaphor is that it can be used to develop new approaches and, furthermore, a metaphor can offer a new path forward when formal logic does not offer a viable solution (Swedberg, 2014). Metaphors can fruitfully clarify interpretations even in most challenging cases representing multiple parallel perspectives (Mann and Warr, 2017). Characteristic to metaphors is that they connect an account of something and an account explaining or predicting a thing (Fforde, 2017).

In the extant business literature, metaphors have been used as a research method in a wide range of contexts. Examples of different contexts include: the assessment of industrial development (Baldwin, et al., 2004; Ehrenfeld, 2004), flexible production systems (Garud and Kotha, 1994), business ethics (Carollo and Guerci, 2018), management studies (Ashcraft, 2013; Paroutis and Heracleous, 2013) and theory building (Weick, 1989; Casciaro and Piskorski, 2005).

Using metaphors in human and natural sciences has a long history. Huneman (2008) has argued that in the Occident, this scientific method has antecedents reaching back at least 2,350 years, and Volkov (2008) has pointed out that metaphors have been used in traditional Chinese science. Famous researchers in the field of biology who have used metaphors as a research methodology include, among others, Carl Linnaeus and Charles Darwin (Pence and Swaim, 2018). 


\section{Literature review}

A problem with contemporary Occidental strategic management is that it is at least partially based on prescriptive speculation - exemplified by concepts like agile manufacturing and lean management. Empirical research on strategic management has thus effectively become speculative research. An epistemological strength of using the metaphor of biological evolution is that it is not subject to speculation. The ancient Greeks tended to speculate on reality, while the ancient Romans tended to be empiricists (Panet, 2010). Using the theories of biological evolution brings engineering innovation research closer to the Roman approach.

There is a fundamental difference between biological evolution and engineering innovation in terms of human judgments: whereas biological evolution is a phenomenon taking place in nature, and thus not subject to human ethical and moral views, humans engage in engineering innovation, and hence, engineering innovation can be evaluated on the basis on ethical and moral views. Similarly, the judgment that engineering innovation is destructive from the standpoint of sustainability (Bossle, 2016) cannot be extended to biological evolution, because nature is not subject to human approval or disapproval.

For the Occident, it is enticing to think that Occidental science and engineering are superior to nonOccidental science and engineering, or even that Occidental science and engineering is the only game in town. This thought has been so completely internalized that it is not spelled out in Occidental literature on engineering innovation, much less being critically questioned. The notion of superiority has become an unquestioned, implicit assumption in the literature on engineering innovation. While the literature on innovation has focused on cooperating with people from different cultural backgrounds (Jehn et al., 1999; Bouncken, 2008), the issue of differences in science and engineering is not addressed. In studies dealing with diversity in national innovation systems (Cassiolato and Martins, 2000; Park and Gwangman, 2003), or global economic integration (Eliasson, 2003), the issue and potential of different types of science and engineering are not addressed. For instance, in a recent assessment of improved innovation potential via venture capital investment (Lee and Kang, 2015), the investment potential for firms using non-Occidental science and engineering was hardly addressed at all.

When diversity in scientific knowledge and engineering are addressed (e.g., Nesta and Dibiaggio, 2003), the studies do not question the global dominance of Occidental science and engineering. Likewise, in assessments of innovation potential (e.g., Holmén et al., 2007), the potential of nonOccidental science and engineering is typically not addressed. An implicit assumption in global production networks (Ruggero et al., 2016) is that they are based on Occidental science and engineering irrespective of the level of autonomy, embeddedness, and performance. Griffin et al. (2017) have argued that cultural diversity among countries has not been recognized in the business literature. The focus on the Occident in an increasingly multi-polar world is probably one of the reasons for the reproducibility and replicability crisis in Occidental science identified by Aguinis et al. (2017).

One potential explanation for the belief of the superiority of the Occident is the Occidental claim of there being only one truth and that the Occident has the only key to this truth, at least since the late Roman Empire. Expressions of Occidental non-syncretism can be found in Occidental Christianity, that is, in the religious wars fought in Europe and the activities of the Holy Inquisition. A higher degree of syncretism, and thus a willingness to contemplate the possibility of different truths, can be observed in the interchange between China and India, for instance in the spreading of Buddhism into China in the $1^{\text {st }}$ century (CE). Even the Greco-Roman world demonstrated a significant level of 
syncretism, as exemplified by the spread of Christianity and Mithraism. Although, syncretism should be part of the proverbial Occidental DNA, it appears to have nearly disappeared some time during the late Roman Empire.

Engineering innovation does not have to occur in-house prima facie. Performance-based contracts are one way to foster innovation (Sumo et al., 2016). Using a partner who is knowledgeable about non-Occidental science and engineering would open the opportunity for an Occidental producer to take advantage of non-Occidental science and engineering in innovation. This would then be reflected in the contract. However, this would require that the Occidental firm is capable and willing to go down this path.

It is necessary to question the explicit and, even more importantly, implicit assumptions underpinning operational strategy, including supply chain management. Thus, it is necessary to move beyond the mechanisms described by MacCarthy et al. (2016). The necessity exists for two major reasons. First, the changes taking place in the global economy are creating significant markets in nonOccidental societies, and it should be assumed that consumers in those particular markets would prefer products and production processes congruent with the domestic traditions. Second, Occidental science and engineering are losing their legitimacy because the environmental and health crises they have significantly contributed to are worsening. For example, WHO (2014) has estimated that seven million premature deaths in $\mathbf{2 0 1 2}$ were the result of hazardous air quality.

Human behavior and the decision-making relating to, for instance, engineering innovation are the result of complex interacting factors. It would be misguided to assume a dichotomy between emotions and knowledge - this calls into question innovation research focusing on knowledge and planning (e.g., Khurana and Rosenthal 1997). Already in the Middle Ages, René Descartes pointed out that emotions - recognizing that the term "emotion" does not have a widely accepted definition - are a source of knowledge (Syssau, 2006). Descartes argued that emotions show what is important to an individual (ibid.). Emotions impact judgment (Brouillet, 2006). Hodgkinson and Healey (2011) observed that dynamic capabilities have both emotional and cognitive roots.

In this paper, biology and biological evolution are an important foundation. They are part of the metaphor that is used to gain a better understanding of engineering innovation. As such, building a metaphor is the research method of the study and by means of the metaphor insights of biology and biological evolution are utilized. It is important to note that there are other approaches by which insights of biology and biological evolution are utilized in engineering and economy. Notable approaches, in this sense, are biomimicry and evolutionary economics.

A modern approach to sustainability is biomimicry. Biomimicry is an approach to innovation that seeks sustainable solutions to human challenges by emulating biological forms, processes, patterns, and systems. The goal is to create products, processes, and policies to support sustainable life on earth in the long term. (Biomimicry Institute, 2019; Kennedy, E.B.; Marting, T.A.; 2016.). In biomimicry, insights of biology and biological evolution are deliberately copied to engineering to enhance engineering innovation. This approach is conceptually different from the approach used for this paper, in which, the metaphor is not used to find direct practical applications but as a central research method by which biology and biological evolution are used as a basis of comparison to increase understanding of a field of science.

Evolutionary economics is an attempt to develop an approach to economics that can amend the deficiencies in traditional economics in explaining economic development. In traditional economic theories, people and institutions are considered as entirely rational actors. Instead, in evolutionary economics human instincts such as curiosity, emulation, and predation are expected to affect 
economic behavior. Furthermore, it is proposed that economic behavior is the result of both individuals and society making choices. (Nelson and Sidney, 1982; Sowell, 1967). The approach in evolutionary economics is conceptually different from the approach of this paper. Evolutionary economics acknowledges that similar evolutionary developments can be observed both in economics and in biological evolution but in evolutionary economics there is no central research method like the metaphor that constitutes an over-arching comparative instrument for increasing understanding.

\section{Global change: the rise of a multipolar world}

Innovation will be significantly impacted by the emergence of a multipolar world ( $O$ 'Sullivan and Subramanian, 2015; Kobrin, 2014; Girod, et al., 2010). A multipolar world is emerging as the result of two factors:

(i) Strengthening of non-Occidental societies: global trade and free-trade agreements have had the effect of making some non-Occidental societies more prosperous. These financial resources are favorable for both the supply side and the demand side of innovation. On the supply side, financial resources enable the financing of projects based on non-Occidental science and engineering. On the demand side, prosperity stimulates demand for products and services based on non-Occidental science and engineering.

(ii) Potential rise of protectionism: in the wake of global trade and free-trade agreements, industrial production has declined and the associated well-paying employment opportunities have been lost in the Occident. This has devastated industrial regions in Europe and North America. One solution to the decline is to rebuild industrial production behind trade barriers - that is to say, a recurrence of protectionism.

To the degree that innovation is driven by demand for innovative products and services, it is necessary to consider where the demand originates. The dominance of the Occident has meant that China, India, and other non-Occidental societies have had to adopt Occidental science and engineering in their exports and in much of their production. The strengthening of non-Occidental economies will result in a renaissance of traditional domestic science and engineering, for example in reinvigorated Sino science and engineering.

The argument that there will be a renaissance in traditional domestic science and engineering is contingent upon a lack of continuity. As a visitor to China can observe, Occidental products command premium prices and are sold in upscale boutiques and malls. The inference is that the Occidental products are considered chic and sophisticated and associated with success. Even in the Chinese market, Chinese firms offer products and services similar to those produced by Occidental firms. Apart from certain niche markets - particularly in beverages, food, and medicine - Occidental science and engineering form the basis for innovation, production, and services. The growing assertiveness of China in international affairs heralds a new sense of pride in Sino history and traditions. This forms the foundation of an increased legitimacy for traditional sino science and engineering. The renaissance in Sino science and engineering will not happen overnight, because significant resources need to be invested before they can seriously challenge Occidental science and engineering.

*** FIGURE $1 * * *$

The current Occidental dominance is a historical anomaly. As shown in Figure 1, the strengthening of multi-polarity will re-establish historical normalcy. 
The strengthening of non-Occidental societies is favored by the weakening of Occidental societies as a result of a serious crisis in the latter. The radicalization of the operational strategy of mass manufacturing from the $14^{\text {th }}$ century onwards (introduction of the Putting-out System) successively cut the connection between engineering, production, and science on the one hand, and ethics, morals, and social preferences on the other. This disconnect reached its zenith with the political implementation of ideologies based on the work of Hayek (2013). The disconnect has deepened as a result of Occidental perception of institutional voids in non-Occidental societies (Doh et al., 2017). Such a perception may be the symptom of the Occidental inability or unwillingness to accept diversity. The result has been deepening and profound environmental and social crises. Such crises can even threaten the legitimacy of Occidental science and engineering. Many of the current environmental crises have been caused by the use of fossil fuels, and are causing climate changes and hazardous air quality. As a result of widening income disparities and cuts to governmental programs, the extant social crises are worsening.

The strengthening of non-Occidental societies raises the prospect of decentralization. The Occident is highly urbanized, but this is not the case in all non-Occidental societies. According to the UN (2014), the share of the urban population was $82 \%$ in North America, $73 \%$ in Europe, $48 \%$ in Asia, and $40 \%$ in Africa in 2014. When producers begin looking for sources of non-Occidental thought patterns and culture, they will likely find them in rural areas and among disadvantaged social groups.

Studies into educational differences suggest that individuals with a non-Occidental background are poorer, live in communities where a non-Occidental language is spoken, and have less Occidental education (Mier y Terán and Rabell, 2013). Education has been used as a tool to integrate nonOccidentals into Occidental societies (Escalona Victoria, 2012; Llanos Erazo, 2013). Non-Occidental cultures are stronger in rural communities than in urban settings (Escalona Victoria, 2012). As a result, the strengthening of non-Occidental societies is associated with decentralization processes favoring rural communities and disadvantaged social groups. Decentralization can be considered a source of increased resilience. From a sustainable development perspective, agriculture in disadvantaged rural areas is likely to be better attuned to ecological factors, thus rendering processes and products based on non-Occidental agriculture practices more sustainable.

The strengthening of non-Occidental societies may entail flexibility, at least at the outset. Urban settings are conducive to the emergence of hybrids of Occidental and non-Occidental thought processes and cultures (Escalona Victoria, 2012). A recognition of the importance of non-Occidental societies by Occidental people living in the same non-Occidental country (Fuentes and de Cea, 2017) creates multi-polarity within the same political boundaries. Urban settings are also conducive to the side-by-side coexistence of traditional communitarian rationality and instrumental rationality - the latter dealing with interaction with Occidental societies - in the same individuals (Rea Campos, 2016). With the strengthening of non-Occidental societies, it is possible that instrumental rationality will diminish in importance in the coming years.

From an environmental perspective, the strengthening of non-Occidental societies will result in major repercussions for projects that are considered illegitimate by non-Occidental societies. The opposition to extraction projects (Alzate Zuluaga, 2011; Sámano Rentería, 2017) heralds these emerging societal changes.

A rise in protectionism would have different repercussions on engineering-related exploitation and exploration. Protectionism may be detrimental to the exploitation of incumbent engineering because tariff and non-tariff trade barriers may prevent trade in the products and services based on incumbent engineering globally. The situation is more nuanced in the case of exploration. If it is 
assumed that protectionism prevents the flow of knowledge and products, then the barriers raised by protectionism may reduce the knowledge transfer required in innovation. Declining economies of scale can enhance this development: the market size may be insufficient to allow for the necessary research and development. If protectionism only limits the flow of products, then using measures like domestic production offers ways to reduce the impact of protectionism, even when only Occidental science and engineering are used in innovation. It must be noted that the current global dominance of Occidental science and engineering has had two-pronged and somewhat contradictory effects. On the one hand, the global dominance of the Occident has eliminated protectionist barriers for knowledge and improved the exploitation of Occidental knowledge. On the other hand, the global dominance of the Occident has been detrimental to non-Occidental science and engineering. This in turn has been detrimental to exploration, particularly outside the confines of Occidental science and engineering.

\section{*** FIGURE $2 * * *$}

The global homogenizing effects of knowledge associated with the global dominance of Occidental science and engineering are problematic. Figure 2 shows that in the same way as geographical isolation increases biodiversity, multi-polarity increases innovation.

Charles Darwin observed biogeographical patterns in the distribution of species and biological differences within the same species (Le Guyader, 2012). The differences allowed species to efficiently take advantage of the opportunities offered by the different environments at different locations. Applying this metaphor to engineering innovation, global homogenization of knowledge weakens innovation efficiency. There are two types of cases in which biological evolution improves efficiency: 1) a species evolves on (anagenesis) and 2) a species splits into two (cladogenesis) (Delsol, 2011). Similar processes are prevented in engineering innovation as the result of the global homogenization of knowledge under the auspices of Occidental science and engineering, and this suggests that the result is inefficiency in engineering innovation. Just as a lack of biodiversity is ecologically inefficient, a lack of diversity in engineering innovation is also inefficient.

\section{Innovation and a multipolar world}

The rise of a multipolar world will threaten the foundations of Occidental science and engineering. Additionally, the Occident will have to deal with environmental and health crises. Assessing the challenges, the biological evolution-based metaphor supports a better understanding of them. This metaphor also has implications for engineering innovation particularly as it relates to diversity and specialization.

Biological evolution in the context of deep crises - as witnessed by mass extinctions - shows the cost of prior success and specialization (Grimoult, 2014): 1) in times of biological mass extinctions, the dominant and specialized species have been at a disadvantage; and 2) the survivors of an extinction and the most successful species after the mass extinction tend to be non-specialized species. In a similar vein, Gould (2006) has argued that evolution takes place in intermittent leaps, while species are relatively stable during much of the time.

These findings should serve as a warning to the Occident, because Occidental science and engineering have long been dominant and they have become quite specialized - the two key warning signs of impending extinction. As signs of extensive specialization in Occidental science, there are not only high barriers between major scientific disciplines, for example between chemistry and physics, but there are also high barriers within major scientific disciplines. These findings also raise the issue of the resilience of non-Occidental science and engineering. What is the fate of Occidental science 
and engineering, if a crisis - or at least the relative weakening of the Occident through increasing global multi-polarity - results in the delegitimation of Occidental science and engineering. In contrast, a major strength of non-Occidental science may be a more holistic, multi-disciplinary view of natural phenomena.

Dominance is not a predictor of future success. In a similar manner as in the case of the clade Dinosauria, which had dominated global fauna for 140 million years but did not hold the keys to continued dominance 65 million years ago, there is no guarantee that Occidental science and engineering will continue to be dominant in the future. The dinosaurs could not prevent the rise to dominance of the mammals. In a similar fashion, evolution and revolutions within the confines of Occidental science and engineering cannot prevent the rise to dominance of one or more nonOccidental traditions of science and engineering. Biological evolution teaches sustainable science and engineering innovation a simple message: no dominance lasts forever.

The research on mass extinctions has come to the tentative conclusion that mass extinctions do not have one single cause, but rather several causes. For example, a sudden meteorite impact could put ecosystems under intense short-term strain, while simultaneous volcanism would put them under long-term strain (Grimoult, 2014). Applying this idea to engineering innovation, the strain that Occidental science and engineering are currently under, as the result of environmental and health crises and the relative weakening of the Occidental, are probably not enough to end the global dominance of Occidental science and engineering. What would be needed, in addition, is a major sudden event, for instance the sudden collapse of Occidental societies as the result of widespread and violent political unrest or outright wars.

Analogous with the loss of diversity as the result of migration facilitated by connections between previously isolated areas (Ledevin et al., 2016), the free movement of engineering results in a loss of diversity in engineering. This in turn narrows the foundation for innovation. In order to increase innovation, biological evolution suggests that it is necessary to increase isolation. This contradicts the underpinnings of free trade. In engineering innovation, this can be understood as a manifestation of exploitation versus exploration, as suggested by March (1991). Free trade is about exploitation, while innovation is about exploration.

The formation of the Isthmus of Panama spelled the extinction of most marsupial species in South America and the extension of a wide range of North American placental mammals. This event is referred to as the Great American Biotic Interchange. It occurred about three million years ago. Before the Great American Biotic Interchange, the migration of species between the Americas had been very limited for the previous nine million years (Woodburne, 2010). Analogously, the dominance of Occidental science and engineering was made possible by the Occidental economic and particularly military dominance of the Americas since the $16^{\text {th }}$ century, of India since the beginning of the $19^{\text {th }}$ century, and of China since the end of the $19^{\text {th }}$ century, thus creating figurative isthmuses. The domestic Amerindian, Indian, and Sino traditions were willfully destroyed, or left to decline in the wake of their delegitimation by the Occident. Just as the placental mammals dominated South American fauna after the Great American Biotic Interchange, so too Occidental science and engineering, with their Greco-Roman roots, have dominated globally for the last centuries. Just as there are some marsupial species (and marsupial genomes) left in the Americas, so too there are some non-Occidental traditions of science and engineering left in the world.

Marsupials competed with some placental mammals in South America - and Antarctica - before the Great American Biotic Interchange (Turner, 2004; Stilwell and Long, 2011). Scholars have debated whether or not some placental mammals evolved in Antarctica (see Pascual and Ortiz Jaureguizar, 
2007). Whether the lack of placental mammals in Australia before the arrival of humans can be interpreted as proof that marsupials were able to outcompete placental mammals is uncertain (Woodburne and Case, 1996). Fossil evidence of marsupials and placental mammals existing side-byside has been found in Antarctica (Goin et al., 1999; Gelfo et al., 2015), which connected South America and Australia during the migration of marsupials and placental mammals from South America to Australia (Godthelp et al., 1992).

The success of marsupials in South America in this time period suggests that placental mammals are not necessarily superior to marsupials, even when there is direct competition. The decimation of South American marsupials in the aftermath of the Great American Biotic Interchange suggests that the North American placental mammals were in a stronger position, at a particular point in time, and under a particular set of circumstances. Future environmental changes may well mean that marsupials are superior under a different set of circumstances.

Diversity resulting from biological evolution strengthens resilience in the face of discontinuous and major changes like the formation of the Isthmus of Panama. Diversity among endemic South American animals meant that not all South American fauna went extinct. Many species disappeared, but some species survived. The survivors did not include apex species like Thylacosmilus and Phorusrhacids. The survival of some endemic South American species, non-apex species, is noteworthy from the standpoint of multi-polarity. Consequently, biological evolution teaches sustainable engineering innovation a fundamental message: diversity resulting from multipolarity of the world strengthens resilience in the face of discontinuous and major changes like environmental issues. Furthermore, non-Occidental engineering may be more resilient because of its embedded higher diversity.

When the fauna of North America and South America before the Great American Interchange are considered jointly, then the separate biological evolution on the two continents demonstrate the greater resilience of decentralization. The separate patterns of biological evolution allowed for the emergence of different species, which were better able to win the competition for survival after the Isthmus of Panama was formed. Here again biological evolution teaches sustainable engineering innovation a useful message: the autonomy and decentralization inherent in multi-polarity enhances the emergence of different types of engineering that are tested through competition, allowing for the most resilient type of engineering to prevail. Furthermore, if this decentralization in engineering is added to decentralized energy generation based on locally available renewables, then another level of resilience is added.

The side-by-side existence of marsupials and placental mammals before the Great American Interchange, and the decimation of the marsupials after the Interchange, suggests that the current global dominance of Occidental science and engineering is not a sign of their intrinsic superiority. Rather, their global dominance is the result of prevailing circumstances, particularly those encompassing the last two centuries. A change in the circumstances may result in a renaissance of non-Occidental science and engineering. This can happen as the result of a number of interacting developments, such as political, environmental and health crises, the strengthening of nonOccidental societies, and more decentralized production (co-engaging production).

The very act of mobilizing non-Occidental science and engineering endangers the survival of at least some types of non-Occidental science and engineering so long as the dominance of Occidental science and engineering persists. South American marsupials only thrived as long as the Isthmus of Panama did not exist. Geographical isolation is an engine of biological diversity (Ledevin et al., 2016). As soon as the Isthmus emerged, many South American species of marsupials faced extinction. 
Similarly, many non-Occidental traditions of science and engineering have survived because of isolation. As soon as Co-engaging Production, particularly powerful ICT, creates a bridge between Occidental and non-Occidental science and engineering, the latter will lose diversity or nonOccidental science and engineering may even face extinction. The diversity of South American marsupials was severely diminished in the same fashion. The issue is how non-Occidental science and engineering can avoid a similar fate. Retaining diversity for sustainable science and engineering will require something that does not have a precedent in biological evolution: conscious effort of strengthening of non-Occidental science and engineering.

The effect of a large landmass on biological evolution is complex. The placental mammals had a large landmass upon which to evolve. The marsupials had already become extinct in Africa, Eurasia, and North America (Giret, 2011). The South American marsupials had been confined to South America for more than 20 million years. Some South American marsupials have survived in ecological niches. Analogously, potential challengers to the dominance of Occidental science and engineering need a niche or a geographical area where they can evolve. One way for a geographical area to emerge and a potential challenger to threaten the dominance of Occidental science and engineering is through the erection of trade barriers. This is analogous to the geographical barriers created by plate tectonics - barriers that allowed for the evolution of biological diversity.

What biological evolution teaches about sustainable engineering innovation, fundamentally challenges many conventional beliefs and, thus, opens up new ways of thinking both in theory building and in practical management. The biological evolution-based metaphor suggests that exploration in engineering innovation that is based on science and engineering may be favored by the erection of barriers and protectionism. This finding, fundamentally contradicts with the view held by economists, beginning with such $18^{\text {th }}$ century physiocrats as François Quesnay and Turgot, and their British successors, Adam Smith and David Ricardo.

However, some aspects of the conclusions drawn from the metaphor between ecological evolution and engineering innovation are similar to conclusions in extant management literature. The migration of placental mammals to South America, is an example of them exploiting the global resources more efficiently, because they were able to commence to exploit the South American resources. The faunal homogenization meant that this came at the cost of diversity, or exploration, as part of biological evolution. A number of strategic management studies acknowledge that inertia caused by resources and routines to support a more efficient exploitation, are detrimental to exploration (Gilbert, 2005; Zhou and Wu, 2010).

\section{Environmental conformity and societal legitimacy}

Biological evolution and engineering innovation are both about change. The change in biological evolution can be piecemeal and slow, or it can be massive and rapid. Piecemeal and slow change has to do with adapting to the environment via genetic changes and mutations. Massive and rapid change is the result of a major event, for instance the strike of a meteorite combined with massive volcanic eruptions, or the formation of the Isthmus of Panama. In both cases, change is confined by the past, that is to say, it is confined by what building blocks were available for biological evolution or engineering innovation. Similarly, already existing inventions (Chesbrough, 2010), in addition to existing engineering and scientific concepts, may become the foundations for innovation as the result of change. Whatever form the change takes, it must be compatible with its environment.

Societal legitimacy in engineering innovation corresponds with environmental compatibility in biological evolution. A nihilistic view would negate the relevancy of societal constraints on 
engineering innovation - a view close to the neoliberalism espoused in Hayek (2013). The issue is that an ideology based on political philosophy is considered by many, to be a scientific truth ipso facto, and it does not need societal legitimization in the view of its adherents - a phenomenon that can be observed in German National Socialism and Anglo-Saxon neoliberalism. A lack of societal legitimacy results in the introduction of processes, products, and services that are not legitimate. Such societal rejection does not need to be immediate. The dynamism of the criteria used to determine societal legitimacy may also render engineering innovation that is illegitimate at a later date as the result of an event like a crisis. In such cases, there is a conflict between societal legitimacy and an ideology, falsely believed to be scientific by its adherents.

From an epistemological standpoint, the juxtaposition of science and societal legitimacy calls into question the validity of the biological evolution-based metaphor vis-à-vis engineering innovation. $A$ potential contradiction can be resolved in two ways. First, humans and their social behavior are the result of evolutionary processes. As such, using the biological evolution-based metaphor cannot contravene societal legitimacy - itself a result of such processes. Second, the metaphor solely describes a process without any claim to its desirability or societal legitimacy. This is different from an ideology, because ideologies are prescriptive.

From an ontological standpoint, the need for environmental conformity in successful biological evolution, and the need for societal legitimacy in successful engineering innovation, is interesting. It suggests that engineering innovation cannot be considered outside of all the complexities of human societies, thus lending credence to the concept of sustainable development. However, this is not sufficient. Since humans are the result of biological evolution, human societies have to exhibit first and foremost environmental conformity. This suggests that environmental sustainability is not equal, but superior to other aspects of sustainability - a view found among many Indigenous peoples (Deroche, 2008; Necefer et al., 2015).

\section{Biological evolution versus human cognition}

One difference between biological evolution and engineering innovation is that biological evolution occurs within the confines of science alone, whereas engineering innovation also contains the element of human cerebral activity, which cannot be solely explained with science. Of importance are the social aspects of human cerebral activity, and particularly, cognition. If there were to be a meaningful difference between biological evolution and engineering innovation, then the cerebral capabilities and the society in which an individual's cognition is formed need to be considered.

Biological evolution impacts the human brain, neuroscientific processes, and cognition. These three evolutionary outcomes bring societal legitimacy and biological evolution together as the result of interactions between the way the human brain works and the way human social behavior works to yield evolutionary advantages in dynamic ecosystems. It is warranted to be careful in assigning a straightforward neuroscientific cause for human behavior, as Gironde (2008) has stressed. At the same time, some steps have been taken to attribute strategic management-related behavior to cerebral areas and processes (Powell, 2011). Over time, human social groups have evolved into complex and large societies. Human actions occur in societies and have to be legitimated in their societies (Li et al., 2017). Neuroscience suggests that there is an interaction between cerebral processes and society (Mason and Morris, 2010). Attempts to separate societal legitimization from engineering innovation would negate the effects of biological evolution - and hence, science - on human actions. 
The renaissance of non-Occidental science and engineering will put Occidentals into the position of having to deal with a multitude of legitimate, non-Occidental traditions of science and engineering after several centuries of Occidental dominance in these fields. Social cognitive neuroscience (Karlsson et al., 2009; Hodgkinson and Healey, 2011) suggests that accepting multipolar traditions of science and engineering will be difficult or even impossible for Occidentals. It cannot be assumed that Occidental science and engineering are always cognitively acceptable outside of the Occident.

In management literature, socio-cognitive processes are typically considered the firm level (Teece et al., 1997; Jansen et al., 2005; Hsiao et al., 2012; Cai and Zhou, 2014; Bundy and Pfarrer, 2015; Liao, 2016). Such an approach fails to recognize that cognition is impacted by the society in question. This failure is tantamount to studying biological evolution at the level of species while disregarding the ecosystem where the species live. A connection between cognition and society has been created in studies dealing with legitimacy (Bitektine, 2011; Bitektine and Haack, 2015; Hoefer and Green, 2016).

\section{Biological evolution and absorptive capacity}

In biological evolution, one way for beneficial new phenotypes to emerge is the procreation of individuals belonging to two populations demonstrating different genotypes and phenotypes. This requires that the individuals can conceive and that the resulting offspring are not sterile. Applying this principle to engineering innovation means that there needs to be sufficient absorptive capacity. Cohen and Levinthal (1990) have argued that absorptive capacity is based on prior related knowledge that "confers an ability to recognize the value of new information, assimilate it, and apply it to commercial ends" (p. 128). Because innovation has a commercial aspect, this characterization is valid for innovation. It establishes a path dependence for innovation that is similar to the genome of a species, because a genome is the result of a path taken during biological evolution. Dynamic absorptive capacity is conducive to resilience (Dawley et al., 2010).

Successful engineering innovation requires external and internal knowledge accumulation for creation to occur (Li and Calantone, 1998; Gao et al., 2016). Figure 3 shows that limited absorptive capacity results in a narrower scientific and engineering foundation in Co-engaging Production.

\section{$* * *$ FIGURE $3 * * *$}

Significant historical differences relating to the absorptive capacity resulting from different societal traditions can be observed. The Occident exhibits a very low absorptive capacity vis-à-vis science and engineering founded on principles other than those found in Greco-Roman philosophy, science, and engineering. When the Occidental reabsorbed Greco-Roman philosophy, science, and engineering from Arab and Byzantine sources at the end of the Middle Ages, some knowledge with roots other than those found in the Greco-Roman world was absorbed as well. The original roots of such knowledge may or may not have been known to the Occident. In the subsequent centuries, the absorption of non-Occidental science and engineering has been limited to exceptions - as a rule, these exceptions have been in the realm of engineering, such as the production of gunpowder, paper, and porcelain. The willful destruction and delegitimization of Amerindian science and engineering in the $16^{\text {th }}$ century was a climax of Occidental hostility toward non-Occidental traditions of science and engineering.

The issue of relevant societal traditions becomes particularly relevant when the acquisition of capabilities for absorptive capacity are considered. Cohen and Levinthal (1990), as well as Zahra and George (2002), have suggested that acquisition is the result of one or several conscious acts. Biological evolution speaks against such an interpretation. It should be remembered that conscious human acts are confined by and occur within society, and that society plays a significant role in the 
formation of an individual's cognition. As societal traditions are the result of historical developments over millennia, impacted by unforeseen events, it is difficult to see acquisition as a result of one or several conscious acts. Just as in biological evolution, also engineering innovation is impacted by a long sequence of crises and events.

Whereas, networks may be inter-societal, they might also offer a way to circumnavigate the cognitive obstacles to absorptive capacity with respect to different societal traditions. The analysis provided by Tortoriello (2015) does not explicitly address such obstacles. When considering the high level of decentralized decision-making in the context of biological evolution, decentralized production might be a way forward in a multipolar world. Moving from centralized production characterized by large firms taking advantage of economies of scale to decentralized production based on fluid networks, would increase the probability of individuals with sufficient absorptive capacity to make use of different traditions of science and engineering while co-engaging in engineering innovation.

\section{Discussion}

The global dominance of Occidental science and engineering can be compared with the existence of land bridges allowing for the migration of species between Africa, Eurasia, and North America before the Great American Biotic Interchange. The inclusion of Africa in the mix adds to the asymmetry discussed by Marshall (1988) and reduces his emphasis on temperate conditions - the relevancy of the temperate conditions argument is doubtful, because North American placental mammals had to win in the subtropical and tropical regions in northern South America before reaching the temperate latitudes of South America. The land bridges may not have been permanent, and there may have been other obstacles - for instance, deserts - from time to time that prevented the migration of species. The existence of land bridges contributed to the reality that placental mammals were the only mammals in Africa, Eurasia, and North America. The absence of marsupials meant that a source of genetic diversity was missing. To put this another way: there was only one platform for mammalian evolution. This constituted a limitation in terms of biological evolution, because the placental mammals did not have to compete against marsupials.

One result of the military and economic dominance of the Occident has been that Occidental science and engineering have been globally dominant for the past few centuries. It has also meant that the Occident relies on only one tradition of science and engineering, just as Africa and Eurasia were relying only on placental mammals. If there were a crisis - similar to the formation of the Isthmus of Panama, which in turn heralded a crisis for South American marsupials - then the lack of alternative platforms to the dominant one may be a fatal shortcoming. An existential crisis of Occidental science and engineering - for instance, their delegitimation as the result of global warming and premature deaths from nitrous oxides and particulate emissions - would be problematic for the Occident. NonOccidental societies would then be in a better position because they could attempt to build an alternative based on non-Occidental traditions of science and engineering.

After the Great American Biotic Interchange, marsupial genes formed a potential foundation for future biological evolution in the interconnected Americas, in-spite of the extinction of numerous South American marsupial species. The absence of marsupial species in Africa and Eurasia, in combination with the Bering Strait, protects placental mammals from potential marsupial competition in Africa and Eurasia for the time being. Genes are not sufficient, on their own, for biological evolution and must be contextualized, as Baylis (2011) has noted. Over the past century, the pendulum has swung back and forth in the debate as to whether genes or the environment determine behavior (Maheu and Macdonald, 2011). One tool used in science and engineering language - is the result of evolution and genetics (Pagel, 2012). In other words, genes have to be 
considered within the context of the relevant ecosystem and - in the case of science and engineering - society. These points offer some insights into decentralized production and its current iteration, Coengaging Production.

The decentralized nature of Co-engaging Production makes it a vehicle for mobilizing non-Occidental science and engineering including knowledge that has survived at the edges of urban centers and in the countryside. Such a mobilization is enabled by powerful information and communications technology. The advent of Co-engaging Production means that there is a broader platform for engineering innovation - as in the case of biological evolution, a broader platform is conducive to more diverse engineering innovation. The knowledge contained in non-Occidental science and engineering can be likened to regional knowledge capabilities. Although, the existing literature on regional knowledge capabilities has a long history and is formally neutral vis-à-vis non-Occidental types of science and engineering the examples used are confined by Occidental science and engineering (Penrose, 1995; Zeller, 2004; Cooke, 2005). The renaissance of non-Occidental science and engineering will test whether the nominal neutrality of science and engineering is factual and whether a new concept has to be developed for a multipolar world.

The Great American Biotic Interchange suggests that the size of the land mass is indicative of the relative strength of ecosystems when they are confronted with competition from other ecosystems. In comparison to marsupials, placental mammals had evolved in a much greater area (Africa, Eurasia, and North America) after the extinction of the dinosaurs. This issue was aggravated by plate tectonics. The southern landmasses (Antarctica, Australia, and South America) have a substantial total area, but plate tectonics - and in the case of Antarctica, glaciation - fragmented the total landmass. South American marsupials facing placental mammals in the Great American Biotic Interchange had faced less competition from within their mammalian infraclass - marsupialia - than had placental mammals. Nevertheless, smaller geographic areas can be dynamos of biological evolution; for example, North America had more biodiversity related to placental mammals than Eurasia in the Eocene (Giret, 2011).

Occidental science and engineering would seem to have a similar advantage as the placental mammals had in the Great American Biotic Interchange: they have a much larger geographical base as the result of their global dominance than any of their potential competitors. There is a decisive difference, however. Whereas, an animal cannot be both a marsupial and a placental mammal, an individual can possess significant knowledge about both Occidental and (at least one type of) nonOccidental science and engineering. This changes the dynamic. In biological evolution, the dynamic is defined by competition alone. In engineering innovation, co-engaging is possible in a way that strengthens both Occidental and non-Occidental science and engineering. The issue is not the genetic impossibility of interspecies breeding, but the absorptive capacity of individuals.

Occidental science and engineering are similar to Africa and Eurasia with respect to biological evolution. Just as there are no marsupial genes in Africa and Eurasia, Occidental science and engineering contain very few roots outside of Greco-Roman philosophy, science, and engineeringJust as the lack of marsupial genes limits the foundations of biological evolution in Africa and Eurasia, the lack of non-Occidental science and engineering limits the foundations of innovation in the Occident.

\section{$* * *$ FIGURE $4 * * *$}

Non-Occidental societies and societies with a strong non-Occidental component are similar to the Americas, as shown in Figure 4. Just as the existence of marsupial genes in the Americas offered a 
foundation for a mammalian biological evolution different from that of placental mammals, the existence of even fragmentary non-Occidental scientific and engineering knowledge offers a foundation for innovation different from that possible within the confines of Occidental science and engineering. Decentralized production will contribute to the renaissance of non-Occidental science and engineering. The emergence of a multipolar world is creating a prerequisite for the renaissance of non-Occidental science and engineering by lending legitimacy to, and creating demand for, products and services based on non-Occidental science and engineering.

\section{Conclusions and outlook}

The contribution of this conceptual paper is that it presents a way to research engineering innovation based on scientific theory and a metaphor. The scientific theory chosen was one that describes a key aspect of dynamic sustainable development, biological evolution. Both biological evolution and engineering innovation deal with complex changes in dynamic environments. Many of the results that were attained by applying the theory of biological evolution in building a metaphor with engineering innovation are such that they could not have been reconciled with views favoring economies of scale and global free trade.

Implications for theory and practice on sustainability are summarized as follows:

(i) Dominance is not forever, and the combined effects of multiple crises can end any form of dominance - the combination of environmental and health crises, a renaissance in several types of non-Occidental science and engineering, and a legitimacy crisis of Occidental governments as a result of the societal strains caused by neoliberalism may be enough to end the global dominance of Occidental science and engineering;

(ii) The dominance of one tradition of science and engineering, currently Occidental science and engineering, can have detrimental effects on engineering innovation;

(iii) Free trade is detrimental to the optimization of products and services that meet local requirements, because this can result in inefficiency;

(iv) Successful engineering innovation requires societal legitimacy, and societal legitimacy requires environmental conformity;

(v) Human cognition is based on cerebral processes that are related to human society. This results in multi-polarity in both human cognition and in science and engineering;

(vi) Dominance reduces absorptive capacity. The currently, dominant Occidental tradition of science and engineering is confronted with such reduced absorptive capacity.

The weaknesses requiring additional research include:

(i) In this paper, the assessment was predominantly based on the Great American Biotic Interchange, which occurred about three million years ago - the assessment should be repeated for other major events related to biological evolution;

(ii) The dynamics of and the prerequisites for the renaissance of a particular type of science and engineering, for instance Sino science and engineering, have not been addressed and require additional research; and

(iii) Despite the fact that neuroscience has found a way into engineering innovation research, the degree and dynamics of the environment versus genetics debate requires a significant amount of additional research to support a better understanding of the role of biological evolution in the cerebral processes associated with engineering innovation. 
Moving engineering innovation research into the realm of science by applying scientific theory developed for biological evolution creates a solid foundation for the development of effective and efficient policies by governments and strategies by firms.

\section{References}

Aguinis, H., Cascio, W.F., Ramani, R.S., 2017. Science's reproducibility and replicability crisis: International business is not immune. Journal of International Business Studies 48, 653-663.

Alzate Zuluaga, M.L., 2011. Responsabilidad social: Hacia un nuevo relacionamiento entre empresas, estado y ciudadanos. Revista Virtual Universidad Católica del Norte 33, 1-21.

Ashcraft, K., 2013. The glass slipper: "Incorporating" occupational identity in management studies. Academy of Management Review 38, 6-31. https://doi.org/10.5465/amr.2010.0219

Baedke, J., Schöttler, T., 2017. Visual metaphors in the sciences: The case of epigenetic landscape images. Journal for General Philosophy of Science 36, 377-391.

Baldwin, J.S., Murray, R., Winder, B., Ridgway, K., 2004. A non-equilibrium thermodynamic model of industrial development: Analogy or homology? Journal of Cleaner Production, 12, 841-853. https://doi.org/10.1016/j.jclepro.2004.02.024.

Baylis, F., 2011. Gene-environment interaction: The gulf between what we know and what we do, in: Maheu, L., Macdonald, R.A. (Eds.), Challenging genetic determinism. McGill-Queens University Press, Montréal, Canada 129-157.

Biomimicry Institute, 2019. https://biomimicry.org/what-is-biomimicry/. (Accessed 26 June 2019).

Bitektine, A., 2011. Toward a theory of social judgments of organizations: The case of legitimacy, reputation, and status. Academy of Management Review 36, 151-179.

Bitektine, A., Haack, P., 2015. The "macro" and the "micro" of legitimacy: Toward a multilevel theory of the legitimacy processes. Academy of Management Review 40, 49-75.

https://doi.org/10.5465/amr.2013.0318

Bossle, M.B., de Barcellos, M.D., Vieira, L.M., Sauvée, L., 2016. The drivers for adoption of ecoinnovation. Journal of Cleaner Production 113, 861-872.

Bouncken, R.B., Ratzmann, M., Winkler, V.A., 2008. Cross-cultural innovation teams: Effects of the four types of attitudes towards diversity. Journal of International Business Strategy 8, 26-36.

Brouillet, D., 2006. Émotion et mémoire, in: Blanc, N., Emotion et cognition: Quand l'émotion parle à la cognition. In Press, Paris, pp. 69-122.

Bundy, J., Pfarrer, M.D., 2015. A burden of responsibility: The role of social approval at the onset of a crisis. Academy of Management Review 40, 345-369. https://doi.org/10.5465/amr.2013.0027

Cai, W., Zhou X., 2014. On the drivers of eco-innovation: Empirical Evidence from China. Journal of Cleaner Production 79, 239-248. DOI: 10.1016/j.jclepro.2014.05.035

Carollo, L., Guerci, M., 2018. 'Activists in a suit': Paradoxes and metaphors in sustainability managers' identity work. Journal of Business Ethics 148, 249-268. 
Casciaro, T., Piskorski, M., 2005. Power imbalance, mutual dependence, and constraint absorption: A closer look at resource dependence theory. Administrative Science Quarterly 50, 167-199. https://doi.org/10.2189/asqu.2005.50.2.167

Cassiolato, J.E., Martins Lastres, H.M., 2000. Local systems of innovation in Mercosur countries. Industry and Innovation 7, 33-53. https://doi.org/10.1080/713670250

Chesbrough, H., 2010. Business model innovation: Opportunities and barriers. Long Range Planning 43, 354-363. http://dx.doi.org/10.1016/j.Irp.2009.07.010

Cohen, W.M., Levinthal, D.A., 1990. Absorptive capacity: A new perspective on learning and innovation. Administrative Science Quarterly 35, 128-152. DOI: 10.2307/2393553

Cooke, P., 2005. Regionally asymmetric knowledge capabilities and open innovation: Exploring 'globalisation 2' - A new model of industry organisation. Research Policy 34, 1128-1149. DOI: 10.1016/j.respol.2004.12.005

Darwin, C., 2013. L'origine des espèces. Seuil, Paris, France.

Dawley, S., Pike, A., Tomaney, J., 2010. Towards the resilient region? Local Economy 25, 650-667. https://doi.org/10.1080/02690942.2010.533424

Delsol, M., 2011. Naissance, vie et mort des espècesbiologiques. Atlantica, Biarritz, France.

Deroche, F., 2008. Les peoples autochtones et leur relation originale à la terre: Un questionnement pour l'ordre mondial. L'Harmattan, Paris, France.

Doh, J., Rodrigues, S., Saka-Helmhout, A., Makhija, M., 2017. International business responses to institutional voids. Journal of International Business Studies 48, 293-307.

Ehrenfeld, J., 2004. Industrial ecology: A new field or only a metaphor? Journal of Cleaner Production 12, 825-831. https://doi.org/10.1016/j.jclepro.2004.02.003.

Eliasson, G., 2003. Global economic integration and regional attractors of competence. Industry and Innovation 10, 75-102. https://doi.org/10.1080/1366271032000068113

Escalona Victoria, J.L., 2012. Perspectivas etnográficas en Chiapas, México, desde una antropología del poder. Revista Mexicana de Sociología 74, 533-560.

Fforde, A., 2017. Confirmation bias: Methodological causes and a palliative response. Quality \& Quantity 51, 2319-2335. DOI: 10.1007/s11135-016-0389-z

Fischer, E., 2014. Philosophical intuitions, heuristics, and metaphors. Synthese 191, 569-606.

Fuentes, C., de Cea, M., 2017. Reconocimiento débil: Derechos de pueblos indígenas en Chile. Perfiles Latinoamericanos 49, 1-21.

Gao, Y., Shu, C., Jiang, X., Gao, S., Page, A.L., 2016. Managerial ties and product innovation: The moderating roles of macro- and micro-institutional environments. Long Range Planning (In Press). http://dx.doi.org/10.1016/j.Irp.2016.11.005.

Garud, R., Kotha, S., 1994. Using the brain as a metaphor to model flexible production systems. Academy of Management Review 19, 671-698. DOI: 10.2307/258741 
Gelfo, J.N., Mörs, T., Lorente, M., López, G.M., Reguero, M., 2015. The oldest mammals from Antarctica, Early Eocene of the La Meseta Formation, Seymour Island. Paleontology 58, 101-110. DOI: $10.1111 /$ pala.12121

Gilbert, C.G., 2005. Unbundling the structure of inertia: Resource versus routine rigidity. Academy of Management Journal 48, 741-763.

Giret, A., 2011. Histoire de la biodiversité. L’Harmattan, Paris, France.

Girod, S., Bellin, J.B. and Ranjan, K.S., 2010. Operating models for a multipolar world: Balancing global integration and local responsiveness. Journal of Business Strategy, 31, 22-27.

Gironde, S., 2008. La neuroéconomie. Plon, Paris, France.

Godthelp, H., Archer, M., Cifelli, R., Hand, S.J., Gilkeson, C.F., 1992. Earliest known Australian tertiary mammal fauna. Nature 356, 514-516.

Goin, F.J., Case, J.A., Woodburne, M.O., Vizcaino, S.F., Reguero, M.A., 1999. New discoveries of "opposum-like" marsupials from Antarctica (Seymour Island, Medial Eocene). Journal of Mammalian Evolution 6, 335-365.

Gould, S.J., 2006. La structure de la théorie de l'évolution. Gallimard, Paris, France.

Griffin, D., Guedhami, O., Kwok, C.C.Y, Li, K., Shao, L., 2017. National culture: The missing countrylevel determinant of corporate governance. Journal of International Business Studies 48, 740-762.

Grimoult, C., 2014. Histoire des theories scientifiques de l'extinction des espèces. Ellipses, Paris, France.

Hampe, M., 2018. Deciding staged battles of the past: On the rhetorics of Olaf Müller's historical philosophy of science. Journal for General Philosophy of Science. https://doi.org/10.1007/s10838017-9397-5.

Hayek, F.A., 2013. Droit, legislation et liberté: Une nouvelle formulation des principes libéraux de justice et d'économie politique. Presses Universitaires de France, Paris, France.

Hodgkinson, G.P., Healey, M.P., 2011. Psychological foundations of dynamic capabilities: Reflexion and reflection in strategic management. Strategic Management Journal 32, 1500-1516.

https://doi.org/10.1002/smj.964

Hoefer, R.L., Green, S.E., 2016. A rhetorical model of institutional decision making: The role of rhetoric in the formation and change of legitimacy judgments. Academy of Management Review 41, 130-150.

Holmén, M., Magnusson, M., McKelvey, M., 2007. What are innovative opportunities? Industry and Innovation 14, 27-45. DOI: 10.1080/13662710601130830

Hsiao, R.-L., Tsai, D.-H., Lee, C.-F., 2012. Collaborative knowing: The adaptive nature of crossboundary spanning. Journal of Management Studies 49, 463-491.

https://doi.org/10.1111/j.1467-6486.2011.01024.x

Huneman, P., 2008. Sur la conception aristotélicienne de l'analogie, in: Durand-Richard, M.-J. (Ed.), L'analogie dans le demarche scientifique: Perspective historique. L'Harmattan, Paris, France 31-60. 
Igbozurike, U.M., 1978. Polyculture and monoculture: Contrast and analysis. GeoJournal 2, 443-449.

Jansen, J.J. P., Bosch, F.A. J. van den, Volberda, H.W., 2005. Managing potential and realized absorptive capacity: How do organizational antecedents matter? Academy of Management Journal 48, 999-1015.

Jehn, K.A., Northcraft, G.B., Neale, M.A., 1999. Why differences make a difference: A field study of diversity, conflict, and performance in workgroups. Administrative Science Quarterly 44, 741-763.

Karlsson, N., Loewenstein, G., Seppi, D., 2009. The Ostrich Effect: Selective attention to information. Journal of Risk and Uncertainty 38, 95-115.

Kennedy, E.B., Marting, T.A., 2016. Biomimicry: Streamlining the front end of innovation for environmentally sustainable products: Research-Technology Management 59, 39-48. https://doi.org/10.1080/08956308.2016.1185342

Khurana, A., Rosenthal, S.R., 1997. Integrating the fuzzy front end of new product development. Sloan Management Review 38, 103-120.

Kobrin, S.J., 2015. Is a global nonmarket strategy possible? Economic integration in a multipolar world order. Journal of World Business, 50, 262-272. DOI: 10.1016/j.jwb.2014.10.003.

Ledevin, R., Chevret, P., Helvaci, Z., Michaux, J.R., Renaud, S., 2016. Bank voles in southern Eurasia: Vicariance and adaptation. DOI: 10.1007/s10914-016-9368-3

Lee, S.U., Kang, J., 2015. Technological diversification through corporate venture capital investments: Creating various options to strengthen dynamic capabilities. Industry and Innovation 22, 349-374. https://doi.org/10.1080/13662716.2015.1054128

Le Guyader, H, 2012. Penser l'évolution. Imprimerie nationale, Paris, France.

Li, D., Zheng, M., Cao, C., Chen, X., Rena, S., Huanga, M., 2017. The impact of legitimacy pressure and corporate profitability on green innovation: Evidence from China Top 100. Journal of Cleaner Production 141, 41-49.

Li, T., Calantone, R.J., 1998. The impact of market knowledge competence on new product advantage: Conceptualization and empirical examination. Journal of Marketing 62, 13-29.

Liao, Z., 2016. Temporal cognition, environmental innovation, and the competitive advantage of enterprises. Journal of Cleaner Production 135, 1045-1053. DOI10.1016/j.jclepro.2016.07.021

Llanos Erazo, D., 2013. Asimetrías y aproximaciones a la problemática educativa de jóvenes indígenas de la Sierra Central ecuatoriana. Ánfora 34, 81-95.

https://doi.org/10.30854/anf.v20.n34.2013.55

MacCarthy, B.L., Blome, C., Olhager, J., Singh, J., Zhao, S.X., 2016. Supply chain evolution - theory, concepts and science. International Journal of Operations \& Production Management 36, 1696-1718.

Maheu, L., Macdonald, R.A.., 2011. The changing boundaries of genes and social environment in perspective: An overview, in: Maheu, L., Macdonald, R.A., Challenging genetic determinism. McGillQueens University Press, Montréal, Canada pp. 3-48. 
Mann, R., Warr, D., 2017. Using metaphor and montage to analyse and synthesise diverse qualitative data: Exploring the local worlds of 'early school leavers'. International Journal of Social Research Methodology 20, 547-558. https://doi.org/10.1080/13645579.2016.1242316

March, J.G., 1991. Exploration and exploitation in organizational learning. Organization Science 2, 71-87.

Marshall, L.G., 1988. Land mammals and the Great American Interchange. American Scientist 76, 380-388.

Mason, M.F., Morris, M.W., 2010. Culture, attribution, and automaticity: A social cognitive neuroscience view. Social Cognitive and Affective Neuroscience 5, 292-306. DOI: 10.1093/scan/nsq034.

Mat, N., Cerceau, J., Shi, L., Park, H.-S., Junqua, G., Lopez-Ferber, M., 2016. Socio-ecological transitions toward low-carbon port cities: Trends, changes and adaptation processes in Asia and Europe. Journal of Cleaner Production 114, 362-375. DOI: 10.1016/j.jclepro.2015.04.058

Merriam-Wester Dictionary. https://www.merriam-webster.com/dictionary/metaphor . (Accessed 21 October 2018).

Mier y Terán, M., Rabell, C., 2013. Escolaridad y lengua hablada en comunidades rurales de la península yucateca. Revista Mexicana de Sociología 75, 371-406.

Necefer, L., Wong-Parodi, G., Jaramillo, P., Small, M.J., 2015. Energy development and Native Americans: Values and beliefs about energy from the Navajo Nation. Energy Research \& Social Science 7, 1-11.

Nelson, R.R., Sidney, G.W., 1982. An evolutionary theory of economic change. The Belknap Press of Harvard University Press, Cambridge, Massachusetts, USA

Nesta, L., Dibiaggio, L., 2003. Technology strategy and knowledge dynamics: The case of biotech. Industry and Innovation 10, 329-347. https://doi.org/10.1080/1366271032000141670

O'Sullivan, M., Subramanian, K., 2015. The end of globalization or a more multipolar world. Credit Suisse Research Institute, 14. 1-48

Pagel, M., 2012. Wired for culture. Norton, London, United Kingdom.

Panet, R., 2010. Les grandes representations du monde et de l'économie. Les liens qui libèrent, Paris, France.

Park, Y., Park, G., 2003. When does a national innovation system start to exhibit systemic behavior? Industry and Innovation 10, 403-414. https://doi.org/10.1080/1366271032000163649

Paroutis, S., Heracleous, L., 2013. Discourse revisited: Dimensions and employment of first-order strategy discourse during institutional adoption. Strategic Management Journal 34, 935-956. https://doi.org/10.1002/smj.2052

Pascual, R., Ortiz-Jaureguizar, E., 2007. The Gondwanan and South American episodes: Two major and unrelated moments in the history of the South American mammals. Journal of Mammalian Evolution 14, 75-137. DOI: 10.1007/s10914-007-9039-5 
Pence, C., Swaim, D., 2018. The economy of nature: The structure of evolution in Linnaeus, Darwin, and the modern synthesis. European Journal for Philosophy of Science 8, 435-454. https://doi.org/10.1007/s13194-017-0194-0

Penrose, Edith T, 1995. The theory of the growth of the firm. Oxford University Press, Oxford, United Kingdom. DOI: 10.1093/0198289774.001.0001

Powell, T.C., 2011. Neurostrategy. Strategic Management Journal 32, 1484-1499. https://doi.org/10.1002/smj.969

Power, J.F., Follett, R.F., 1987. Monoculture. Scientific American 256, 78-87.

Rentetzi, M., 2005. The metaphorical conception of scientific explanation: Rereading Mary Hesse. Journal for General Philosophy of Science 36, 377-391.

Rea Campos, C.R., 2016. Complementando racionalidades: La nueva pequeña burguesía aymara en Bolivia. Revista Mexicana de Sociología 78, 375-407.

Ruggero, G., Deflorin, Pa., Scherrer, M., 2016. Exploiting the potential of manufacturing network embeddedness. International Journal of Operations \& Production Management 36, 1741-1768.

Sámano Rentería, M.Á., 2017. Movimientos de resistencia campesina e indígena contra los megaproyectos y el modelo extractivista. El Cotidiano 201, 7-16.

Schlanger, J., 1995. Connaissance et métaphore. Revue de synthèse 116, 579-592.

Schumpeter, J., 1963. Capitalisme, socialisme et démocratie. Payot, Paris, France.

Sowell, T., 1967, The 'evolutionary' economics of Thorstein Veblen. Oxford Economic Papers, 19, 177-198.

Stilwell, J.D., Long, J.A., 2011. Frozen in time. CSIRO Publishing, Collingwood, Australia. DOI: 10.1111/j.1095-8312.2012.01932.x

Sumo, R., Valk, W. van der, Weele, A. van; Bode, C., 2016. Fostering incremental and radical innovation through performance-based contracting in buyer-supplier relationships. International Journal of Operations \& Production Management 36, 1482-1503.

Syssau, A., 2006. Émotion et cognition, in: Blanc, N., Emotion et cognition: Quand l'émotion parle à la cognition. In Press, Paris, pp. 11-68.

Teece, D.J., Pisano, G., Shuen, A., 1997. Dynamic capabilities and strategic management. Strategic Management Journal 18, 509-533.

Tortoriello, M., 2015. The social underpinnings of absorptive capacity: The moderating effects of structural holes on innovation generation based on external knowledge. Strategic Management Journal 36, 586-597. https://doi.org/10.1002/smj.2228

Turner, A., 2004. Prehistoric mammals. Firecrest Books, Washington, DC, USA.

UN, 2014. World urbanization prospects: The 2014 revision (Highlights).

https://esa.un.org/unpd/wup/Publications/Files/WUP2014-Highlights.pdf (Accessed 16 August 2017). 
Volkov, A., 2008. Raisonnement par analogie dans les mathématiques chinoises du premier millénaire de notre ère, in: Durand-Richard, M.-J. (Ed.), L'analogie dans le demarche scientifique: Perspective historique. L'Harmattan, Paris, France 61-96.

Wall, A., 2009. Myth, metaphor and science. Chester University Press, Chester, United Kigdom.

Walsh, D.M., 2003. Fit and diversity: Explaining adaptive evolution. Philosophy of Science 70, 280301. DOI: $10.1086 / 375468$

Weick, K., 1989. Theory construction as disciplined imagination. Academy of Management Review $14,516-531$.

Wells, P., 2013. Diversity, scale and sustainability in human systems: Towards a research agenda. Journal of Cleaner Production 47, 232-235. DOI: 10.1016/j.jclepro.2012.06.011

WHO, 2014. 7 Million premature deaths annually linked to air pollution. http://www.who.int/mediacentre/news/releases/2014/air-pollution/en/ (Accessed 2 December 2016).

Woodburne, M.O., Case, J.A., 1996. Dispersal, vicariance, and the Late Cretaceous to Early Tertiary land mammal biogeography from South America to Australia. Journal of Mammalian Evolution 3, 121-161. DOI: 10.1007/BF01454359

Woodburne, M.O., 2010. The Great American Biotic Interchange: Dispersals, tectonics, climate, sea level and holding pens. Journal of Mammalian Evolution 17, 245-264. DOI: 10.1007/s10914-0109144-8

Zahra, S.A., George, G., 2002. Absorptive capacity: A review, reconceptualization, and extension. Academy of Management Review 17, 185-203. DOI: 10.2307/4134351

Zeller, C., 2004. North Atlantic innovative relations of Swiss pharmaceuticals and the proximities with regional biotech arenas. Economic Geography 80, 83-111.

Zhou, K.Z., Wu, F., 2010. Technological capability, strategic flexibility, and product innovation. Strategic Management Journal 31, 547-561. https://doi.org/10.1002/smj.830 

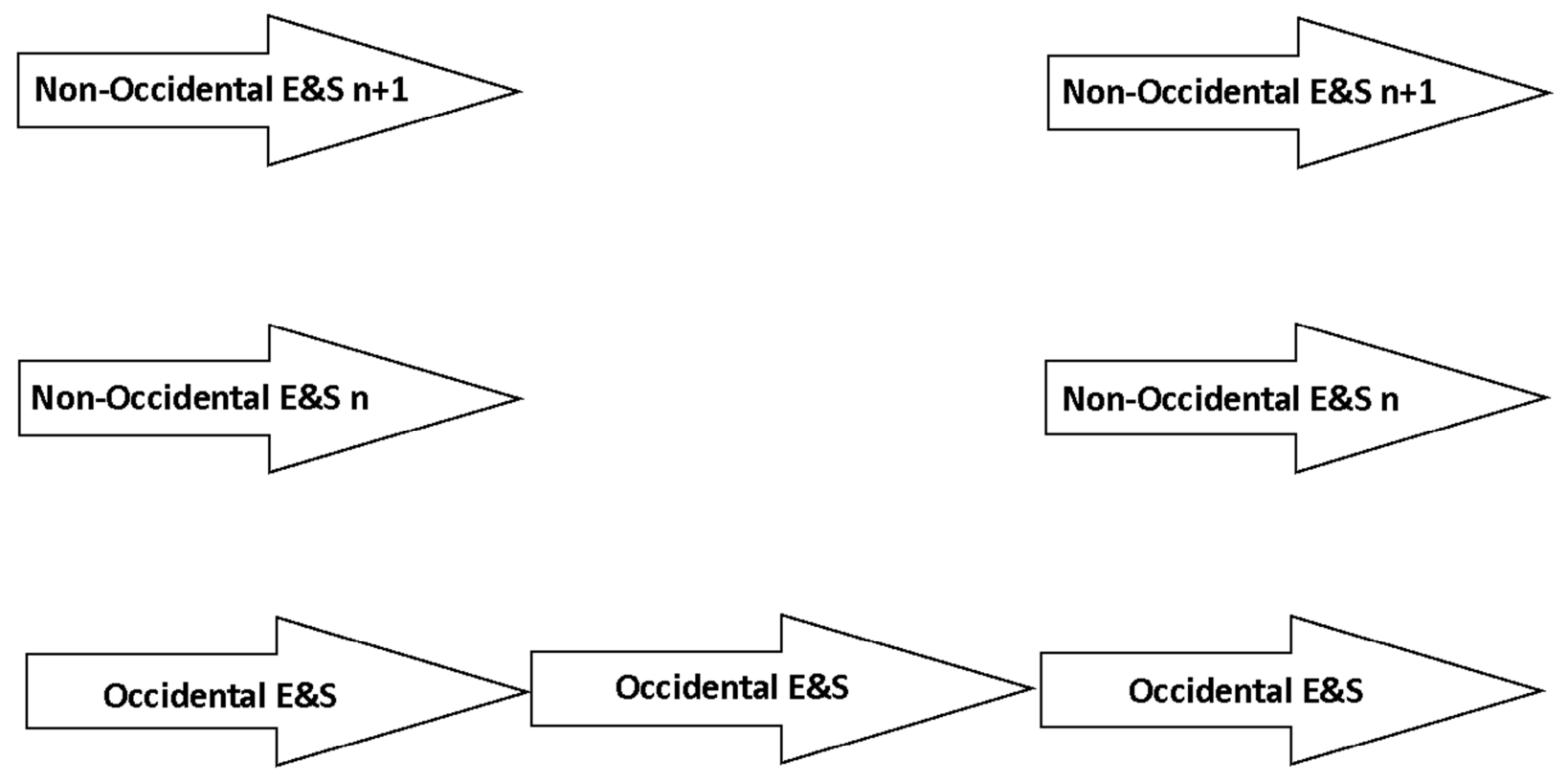

Past

Multi-polarity
Current

Occidental Dominance
Future

Multi-polarity

Figure 1: The current dominance of Occidental science and engineering (S\&E) is a historical anomaly, an anomaly that the strengthening of multi-polarity in the future will reverse. 


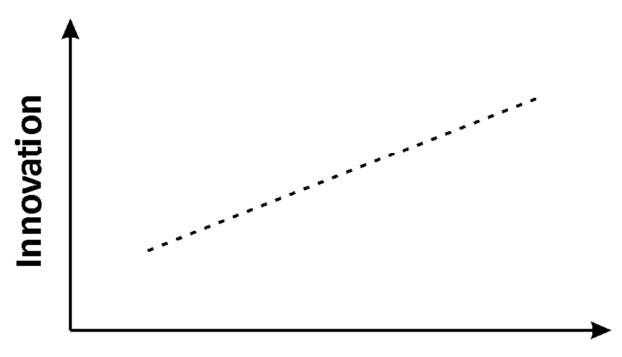

Multi-polarity

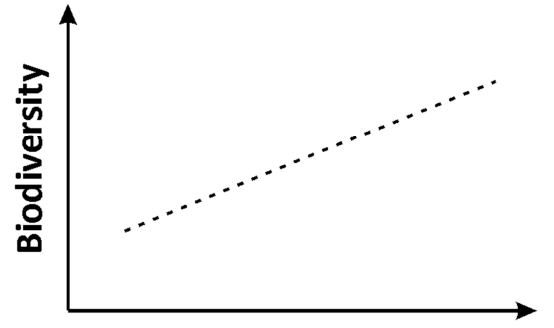

Geographical Isolation

Figure 2: Multi-polarity increases engineering innovation in a similar fashion than geographical isolation increases biodiversity. 


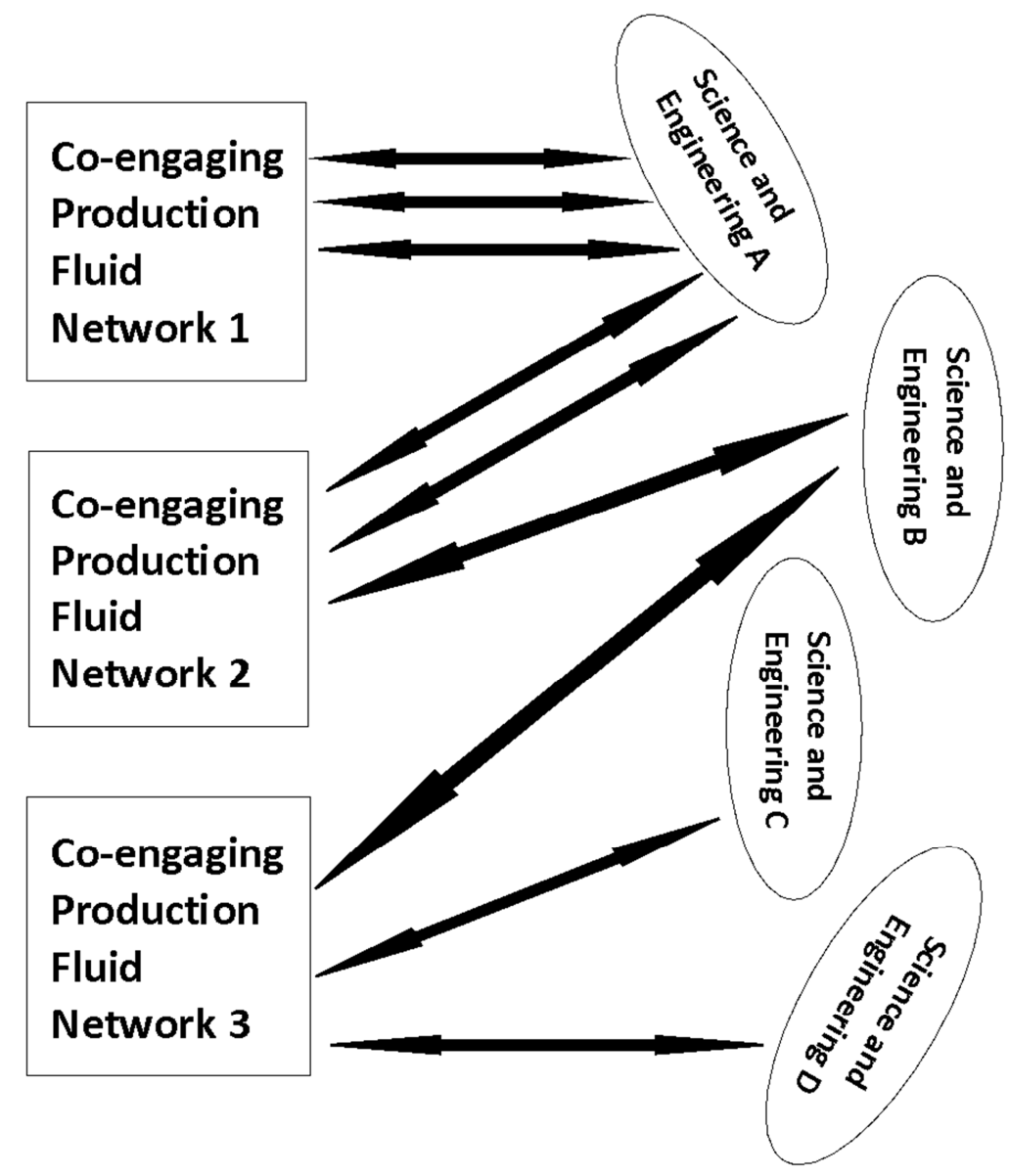

Fiqure 3: Limited absorptive capacity results in reduced cognitive distance, thus reducing the engineering and scientific foundation in the case of the Co-engaging Production Fluid Network 1. The issue here is that individuals hailing from other foundations are not self-selected. The Co-engaging Production Fluid Network 3 demonstrates a broader foundation, and thus it takes advantage of global multi-polarity. 


\section{Biological Evolution}
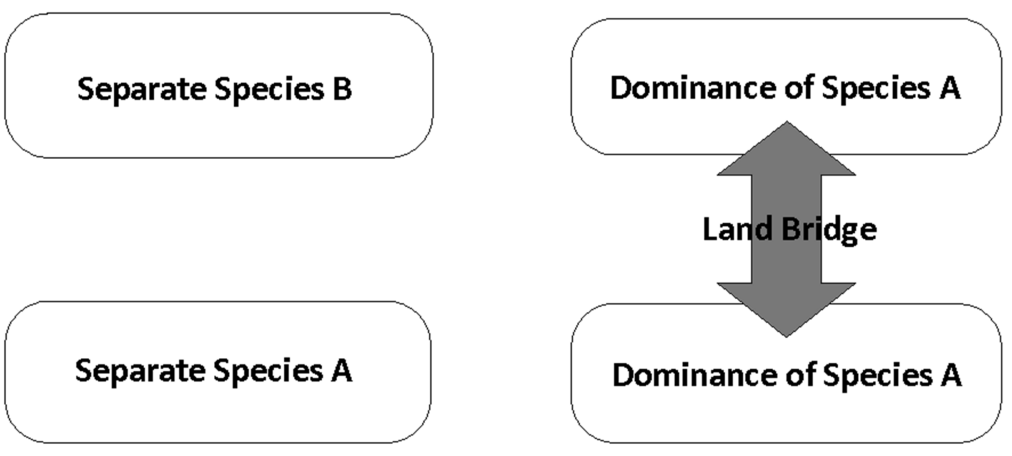

\section{Engineering Innovation}
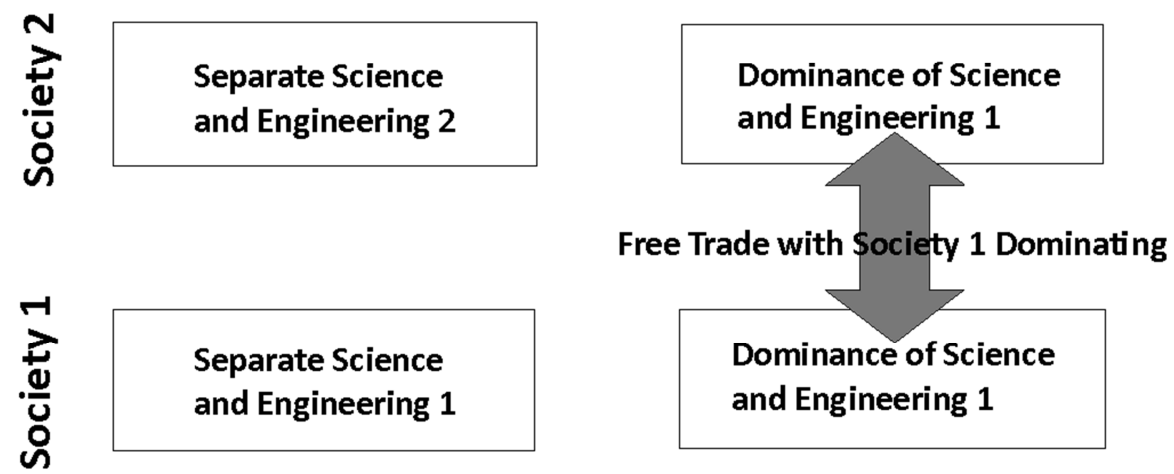

Figure 4: In the upper illustration concerning biological evolution, the effect of a land bridge is depicted. Accordingly, the co-existence of a separate species $A$ and a separate species $B$ will change to the dominance of the species $A$ as a result of the emergence of a land bridge. This development leads loss of genetic diversity.

In the lower illustration concerning engineering innovation, the effect of free trade is depicted. Accordingly, the co-exitance of a separate science and engineering $A$ and a separate science and engineering $B$ will change to the dominance of the science and engineering $A$ as a result of the introduction of free trade in which society $A$ is dominating. This development leads to loss of engineering and scientific diversity. 